F. Reprod. Fert. (1966) 12, 221-224

BRIEF COMMUNICATION

\title{
INFLUENCE OF BODY WEIGHT UPON CORPUS LUTEUM FORMATION AND MAINTENANCE OF PREGNANCY IN THE RABBIT
}

\author{
R. E. STAPLES* AND DORSEY E. HOLTKAMP \\ Department of Endocrinology, Scientific Laboratories, The William S. Merrel Company, \\ Division of Richardson-Merrell Inc., Cincinnati, Ohio, U.S.A. \\ (Received 29th September 1965, revised 10th Fanuary 1966)
}

Mature female rabbits readily ovulate and form functional corpora lutea (CL) if given exogenous luteinizing hormone ( $\mathrm{LH})$. $\mathrm{LH}$ was routinely administered to artificially inseminated Dutch-Belted does to initiate pregnancies successfully for teratology experiments (Staples \& Holtkamp, 1963); however, it was noted that fewer pregnancies resulted among small, supposedly mature, does obtained from commercial suppliers. It was realized that, if body weight was related to response to LH administration among such small does of unknown age, a guideline was necessary for pre-selection of responding from non-responding does. This study was conducted to provide an estimate of the incidence of LHinduced GL formation and maintenance of pregnancy among supposedly mature does of varied weight groups.

Thirty-two young, virgin, Dutch-Belted does were individually caged for 18 days. Body weights were recorded and each doe was injected intravenously with $1.0 \mathrm{mg}$ of $\mathbf{~ L H} / \mathrm{kg}$ (PLH, Armour). Laparotomies were performed 18 days later and the ovaries were examined for the presence or absence of CL. On the following day body weights were recorded, and twenty-six of the does were again injected with LH and then artificially inseminated. On the 25th day after insemination laparotomies were performed. Adams (1960) reports that such laparotomies do not increase prenatal mortality. Three days later body weights were again taken, and the eighteen non-pregnant does were given $\mathrm{LH}$ and artificially inseminated. All eighteen does were autopsied 30 days later and their reproductive status determined. Point biserial coefficients (Edwards, 1954) were calculated to determinate the relationships between body weight and incidence of CL or pregnancy. The relationship between body weight and litter size (Table 1) was determined by regression analysis (Snedecor, 1956).

The effect of body weight upon the incidence of CL formation (Text-fig. 1) was highly significant $(P<0.01)$. CL were nevertheless present in two of twelve does that weighed between 0.95 and $1.14 \mathrm{~kg}$. One of these two does weighed only $1.05 \mathrm{~kg}$ and maintained two foetuses with a total of only two CL.

In Table 1 the number of does with CL and the number pregnant is presented,

* Present address: The Worcester Foundation for Experimental Biology, Shrewsbury, Massachusetts.

$\mathrm{H}$ 
as well as litter size for the does given $\mathbf{L H}$ and artificially inseminated. The proportion of inseminated females becoming pregnant $(P<0.01)$, and the average litter size $(P<0 \cdot 05)$ both increased significantly with body weight.

The effect of body weight on CL formation and on maintenance of pregnancy could not be isolated from the effect of repeated LH injections or from the possible effect of one or two laparotomies. For this reason, additional information

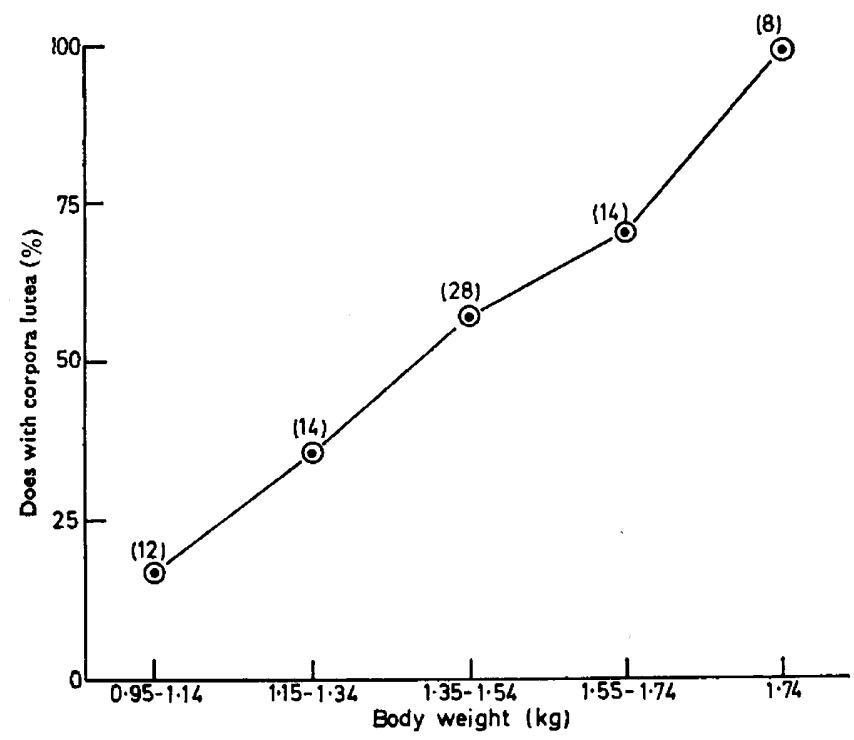

TEXT-FIG. 1. Percentage of various-sized does with corpora lutea after LH administration (combined results after first, second, and third LH administration). The numbers in parentheses are the numbers of observations.

TABLE 1

RELATIONSHIP BETWEEN BODY WEIGHT AND REPRODUGTIVE STATUS AMONG INSEMINATED DOES (COMBINED RESULTS AFTER SECOND AND THIRD ADMINISTRATION ONLY)

\begin{tabular}{|c|c|c|c|c|}
\hline \multirow{2}{*}{$\begin{array}{c}\text { Body wt } \\
(k g)\end{array}$} & \multicolumn{3}{|c|}{ No. of does } & \multirow{2}{*}{$\begin{array}{c}\text { Average } \\
\text { No. of foetuse } \\
( \pm \text { S.E. })\end{array}$} \\
\hline & Total & $\begin{array}{c}\text { Corpora lutea } \\
\text { present }\end{array}$ & Pregnant & \\
\hline $\begin{array}{r}0.95 \text { to } 1.14 \\
1.15 \text { to } 1.34 \\
1.35 \text { to } 1.54 \\
1.55 \text { to } 1.74 \\
>1.74\end{array}$ & $\begin{array}{r}1 \\
4 \\
18 \\
13 \\
8\end{array}$ & $\begin{array}{r}1 \\
1 \\
10 \\
9 \\
8\end{array}$ & $\begin{array}{l}1 \\
1 \\
8 \\
8 \\
7\end{array}$ & $\begin{array}{l}2 \cdot 0 \\
0.0^{*} \\
3 \cdot 8 \pm 0.75 \\
5.4 \pm 0.93 \\
6.0 \pm 0.58\end{array}$ \\
\hline
\end{tabular}

* One female had one resorption site not included in the Table.

was derived from 114 non-laparotomized does that served as cumulative controls in a series of other studies. These results are presented in Table 2. There was a significant positive association $(P<0.05)$ between body weight and the proportion of does possessing $\mathrm{CL}$. $\mathrm{R} \times \mathrm{C}$ Chi-square analysis (Snedecor, 1956) revealed a highly significant difference among body weight groups 
regarding the incidence of pregnancy $(P<0 \cdot 01)$; however, a significant correlation (Edwards, 1954) between body weight and pregnancy incidence was not found. The latter finding was probably due to the large number of does weighing more than $1.74 \mathrm{~kg}$. Pregnancy failure among does weighing $1.74 \mathrm{~kg}$ or more was not due to insufficient body weight. There was a significant increase with body weight in the percentage of does possessing corpora lutea $(P<0.05)$ and in the percentage of total maintaining pregnancy $(P<0.01)$. Some of the larger does $(>1.74 \mathrm{~kg})$ that had only four or fewer $\mathrm{CL} /$ doe were able to maintain the pregnancy whereas the smaller does were not able to do so. Also, the larger does had a higher percentage of litters of more than five kits.

These cumulative results on non-laparotomized animals support the data obtained on laparotomized animals in that body weight is related to the incidence of $\mathrm{CL}$ formation and to the maintenance of pregnancy. Best responses were again attained if the does weighed more than $1.74 \mathrm{~kg}$.

The response was lower than that obtained among the does that were laparotomized. The difference may be due to the fact that the cumulative control data were obtained during the various seasons occurring over a period of $1 \frac{1}{2}$ years.

TABLE 2

CUMULATIVE INFORMATION FROM 114 NON-LAPAROTOMIZED CONTROL DOES GIVEN A SINGLE DOSE OF LH

\begin{tabular}{c|c|c|c|c|c|c|c|c}
\hline $\begin{array}{c}\text { Body wt } \\
(\mathrm{kg})\end{array}$ & $\begin{array}{c}\text { Total } \\
\text { No. }\end{array}$ & $\begin{array}{c}\text { No. of does } \\
\text { ovulated } \\
\left(\mathrm{CL}^{*}\right)\end{array}$ & $\begin{array}{c}\text { Does } \\
\text { ovulated } \\
(\%)\end{array}$ & $\begin{array}{c}\text { Av. No. } \\
\mathrm{CL} \\
( \pm S . E .)\end{array}$ & $\begin{array}{c}\text { No. of does } \\
\text { pregnant }\end{array}$ & $\begin{array}{c}\text { Does } \\
\text { maintaining } \\
\text { pregnancy } \\
(\%)\end{array}$ & $\begin{array}{c}\text { Average } \\
\text { litter size } \\
( \pm S . E .)\end{array}$ & $\begin{array}{c}\text { No.of does } \\
\text { with }>5 \\
\text { young }\end{array}$ \\
\hline 0.95 to 1.14 & - & - & - & - & - & - & - & - \\
1.15 to 1.34 & 4 & 1 & 25 & 5.0 & 1 & 100 & 5.0 & 0 \\
1.35 to 1.54 & 14 & 10 & 71 & $5 \cdot 7 \pm 0.84$ & 5 & 50 & $4.8 \pm 1.20$ & $1(20 \%)$ \\
1.55 to 1.74 & 18 & 13 & 72 & $7.2 \pm 0.92$ & 8 & 61 & $4.8 \pm 0.35$ & $2(25 \%)$ \\
$>1.74$ & 78 & 70 & 90 & $7.1 \pm 0.37$ & 55 & 78 & $4.9 \pm 0.25$ & $28(52 \%)$ \\
\hline
\end{tabular}

* Corpora lutea.

A single intravenous injection of $\mathbf{L H}$ into the mature Dutch-Belted doe was previously reported to result in ovulation in virtually every animal (Foote, Hafs, Staples, Gregoire \& Bratton, 1963). After similar LH administration to thirty-two smaller Dutch-Belted does in this study, only eleven had cL when laparotomized 18 days later. Either one or two subsequent injections of $\mathbf{L H}$ administered as the does gained weight resulted in pregnancies in all but two of the twenty-six does tested. Thus body weight was related to LH-induced CL formation among such does, even though Emmens (1939) reported 'Dutch' does to be mature when a weight of approximately $1 \mathrm{~kg}$ was attained. The incidence of corpus luteum formation was low among does weighing between 1.35 and $1.54 \mathrm{~kg}$, but if CL formed, these does maintained pregnancy as well as did the heavier does. Among the smaller does of less than $1.54 \mathrm{~kg}$ body weight, litter size was smaller. The results of this study indicate that, if age is unknown, it is important to use does that weigh $1.75 \mathrm{~kg}$ or more for critical reproduction studies. 
The authors are grateful to Miss Carol J. Carl, Mr R. D. Strain and Mr M. T. Anderson for their technical assistance.

\section{REFERENCES}

Adams, C. E. (1960) Studies on prenatal mortality in the rabbit, Oryctolagus cuniculus: the amount and distribution of loss before and after implantation. F. Endocr. 19, 325.

EDwards, A. L. (1954) Statistical methods for the behavioral sciences, p. 182. Rinehart, New York.

Emmens, C. W. (1939) Growth of the reproductive and endocrine organs of the female rabbit. F. Endocr. $1,409$.

Foote, R. H., Hafs, H. D., Staples, R. E., Gregorre, A. T. \& Bratton, R. W. (1963) Ovulation rates and litter sizes in sexually receptive and nonreceptive artificially inseminated rabbits given varying dosages of luteinizing hormone. J. Reprod. Fert. 5, 59.

SNEDecor, G. W. (1956) Statistical methods, 5th edn, pp. 122 and 225. Iowa State College Press, Ames, Iowa.

Staples, R. E. \& HoltKamp, D. E. (1963) Effects of parental thalidomide treatment on gestation and fetal development. Exp. molec. Pathol., Suppl. 2, 81. 